Article

\title{
Surveying and High-Resolution Topography of the Ochtiná Aragonite Cave Based on TLS and Digital Photogrammetry
}

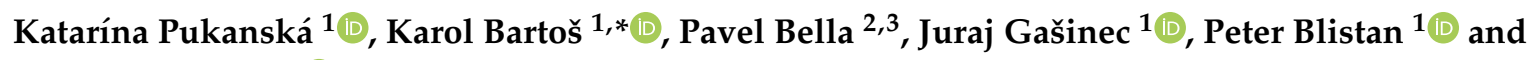 \\ L'udovít Kovanič ${ }^{1}$ (i) \\ 1 Institute of Geodesy, Cartography and GIS, Faculty of Mining, Ecology, Process Control and \\ Geotechnologies, Technical University of Košice, Park Komenského 19, 04001 Košice, Slovakia; \\ katarina.pukanska@tuke.sk (K.P.); juraj.gasinec@tuke.sk (J.G.); peter.blistan@tuke.sk (P.B.); \\ ludovit.kovanic@tuke.sk (L'.K.) \\ 2 Department of Geography, Faculty of Education, Catholic University in Ružomberok, Hrabovská cesta 1, \\ 03104 Ružomberok, Slovakia; pavel.bella@ssj.sk \\ 3 State Nature Conservancy of the Slovak Republic, Slovak Caves Administration, Hodžova 11, \\ 03101 Liptovský Mikuláš, Slovakia \\ * Correspondence: karol.bartos@tuke.sk; Tel.: +421-55-602-2978
}

Received: 27 May 2020; Accepted: 2 July 2020; Published: 4 July 2020

\begin{abstract}
The Ochtiná Aragonite Cave (Slovakia, Central Europe) is a world-famous karst phenomenon of significant geological, geomorphological, and mineralogical values. Its specific origin is determined by particular lithological and hydrogeological conditions of the Ochtiná karst formed in lenses of Paleozoic crystalline limestones, partly metasomatically altered to ankerite and siderite. Although the cave is only $300 \mathrm{~m}$ long, it represents a combined labyrinth consisting in parallel tectonically controlled halls and passages, that are largely interconnected through transverse conduits of phreatic and epiphreatic morphology with many medium- and small-scale forms originated in slowly moving or standing water (flat solution ceilings, wall inward-inclined facets, water table notches, convectional cupolas, and spongework-like hollows). The highly dissected and irregular morphologies of the cave were surveyed with terrestrial laser scanning and digital photogrammetry. Both used surveying technologies proved to be suitable for quick and accurate mapping of the complicated cave pattern. While terrestrial laser scanning can provide a rapid survey of larger and more complex areas with results delivered directly in the field, digital photogrammetry is able to generate very high-resolution models with quality photo-texture for mapping of small-scale morphologies. Several data on cave morphometry were generated from terrestrial laser scanning (e.g., the area of cave ground plan, the peripheral surface of underground spaces, and their volume). The new detailed map, sections, and 3D model create an innovation platform for a more detailed study on the morphology and genesis of this unusual cave also for its environmental protection and use in tourism.
\end{abstract}

Keywords: 3D mapping; terrestrial laser scanning; structure-from-motion; cave morphology; morphostratigraphy; flat ceiling; cupola; facets; cusped depression

\section{Introduction}

The Ochtiná Aragonite Cave (Revúcka vrchovina Mountains, southern Slovakia) is associated with the World Heritage property "Caves of Aggtelek Karst and Slovak Karst" from 1995. It is famous and significant not only for its rich and rare aragonite decoration but also because of the specific solution phreatic morphologies; mainly flat ceilings and facets. However, the complex morphology of 
this cave, especially of its medium- and small-scale morphologies, is not sufficiently visualized on the existing speleological maps.

The maps of the Ochtiná Aragonite Cave from 1955, 1956, and 1983 (see [1-4]) display predominantly the ground plan. Cross and longitudinal sections of cave passages and halls are not sufficiently frequent and precise. Only some cross and longitudinal sections along the tourist path were more precisely measured [5]. Many other cross-sections were completed while measuring the location of technical facilities in the cave [6]. However, the contours of passages and halls in the existing maps are not exactly accurate over their entire length. In addition to that, medium- and small-scale morphologies (e.g., cupolas and smaller spherical cavities deepened into the ceiling, flat ceilings, and facets) are not displayed, although they are important for a more detailed morphological study or the inventory and protection of aragonite forms. Classic surveying and mapping of bedrock surfaces with such irregular and rugged morphologies is much more time-consuming and mostly less precise. For this reason, terrestrial laser scanning was used for the new geodetic surveying and 3D mapping of the cave.

\section{Study Site}

The Ochtiná Aragonite Cave is located on the north-western slope of Hrádok hill (809 m a.s.l.) in the Revúcka vrchovina Mountains (Figure 1). It is formed in the isolated lens of Lower Devonian crystalline limestones (marble), which were partly metasomatically altered into ankerite and siderite during hydrothermal ore mineralization of the Hrádok massif by magnesium-ferrous thermal solutions $([1,7,8]$ and others). The lens of these carbonates is surrounded by insoluble graphitic and sericitic-graphitic phyllites (karst barré). Its underground cavities are a result of the dissolution of limestone and the oxidation of ankerite forming ochres [8-11]. It can be assumed that the crystalline limestones were more intensively dissolved due to the release of $\mathrm{CO}_{2}$ during the oxidation of siderite and ankerite by the effect of oxygenated meteoric waters, which seeped into the cave through the overlying fractured phyllites [12,13]. Recently, underground waters from the cave leak out to the north-eastern slope of Hrádok hill into the brook in the Banská valley (springs are situated about $100 \mathrm{~m}$ lower than the cave).

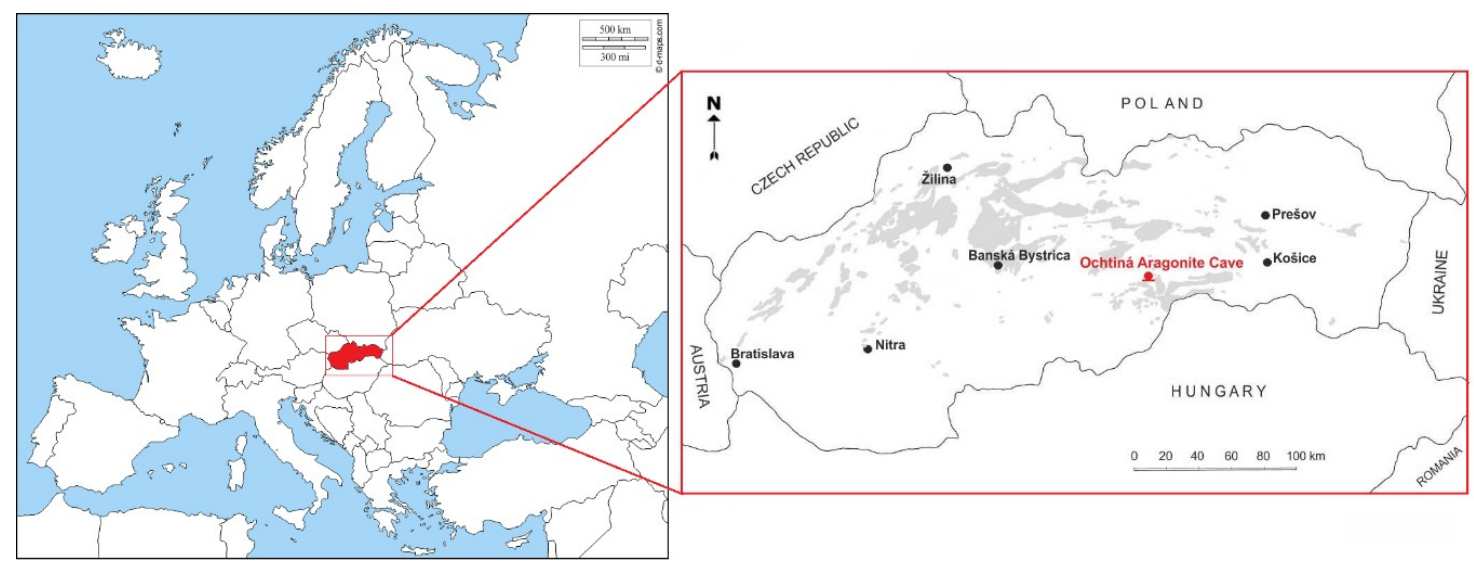

Figure 1. Location of the Ochtiná Aragonite Cave.

The cave, with a length of $300 \mathrm{~m}$, has several remarkable phreatic and epiphreatic solution morphologies that originated in slowly moving (due to thermohaline conventional flows in a rather isolated environment of the carbonate lens) or standing water [12-14] (Figure 2). In addition to ceiling cupolas and numerous smaller spherical cavities or spongework-like hollows, several parts of this cave are featured by well-developed triangular or trapezoidal cross-sections consisting of a flat ceiling ("Laugdecken"- [15], and others) and inward-sloping smooth walls or facets ("Facetten" in the sense of [15] and others or planes of repose in the sense of [16]). Ford and Williams [17] refer that the 
Ochtinská Aragonite Cave is an excellent example of "notch caves" originated by lateral corrosion along the standing water.

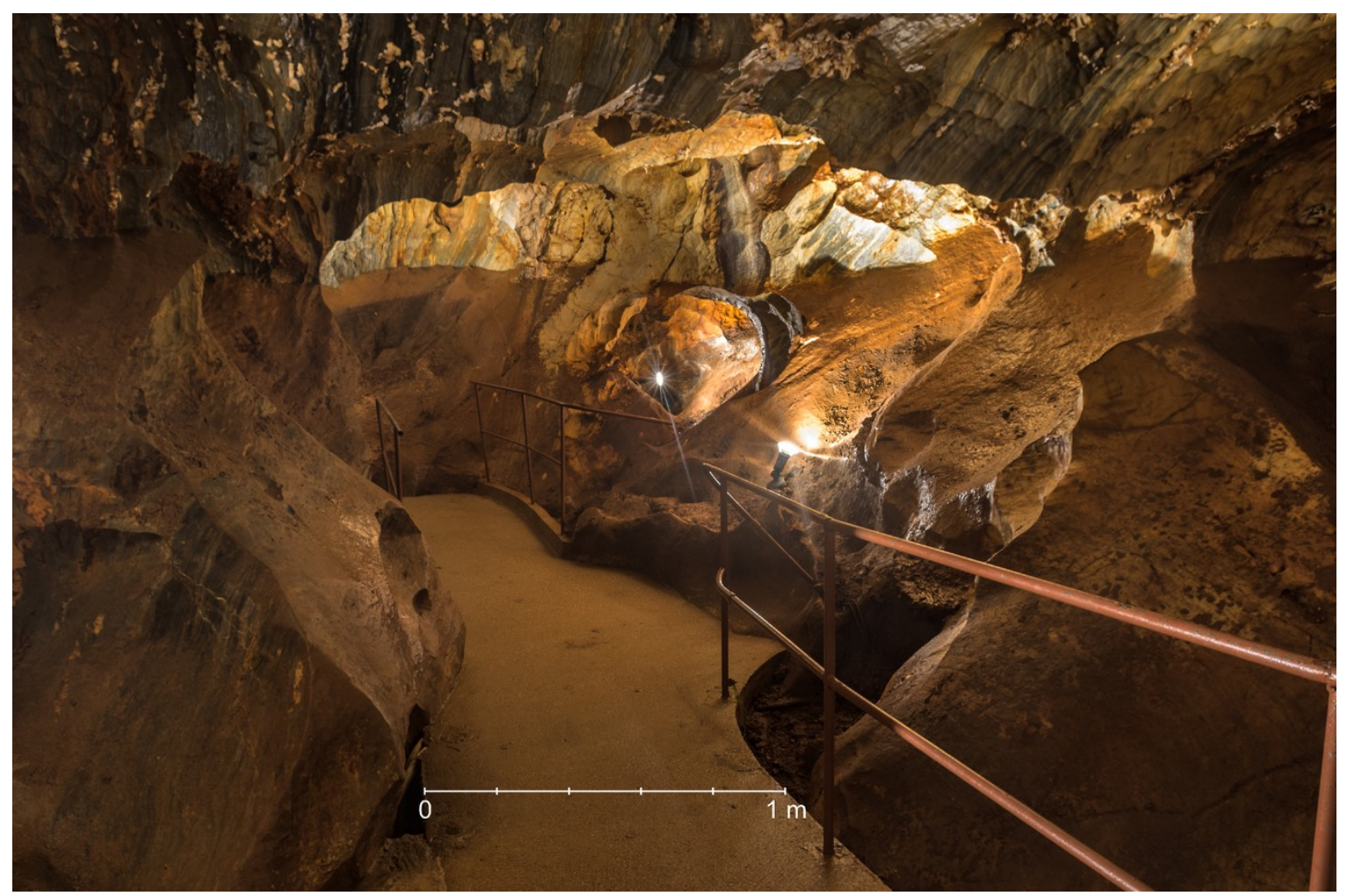

Figure 2. Morphology of phreatic passage with wall inward-sloping smooth solution facets in Ochtiná Aragonite Cave.

The oldest generation of aragonite are milky translucent kidney-shaped formations and their corroded remains (dated age of 121-138 ka) with partly recrystallized aragonite, in places metamorphosed to calcite. The prevailing second generation of aragonite occurs mostly as several $\mathrm{cm}$ long needles and spiral helictites (dated age of $14 \mathrm{ka}$ ) forming clusters or dentritic formations [11]. Aragonite of this generation is still growing, which enables it to maintain its white color and clean appearance (Figure 3). The youngest generation of aragonite, which is being formed at present on sediments and iron ochres makes tiny fans (mostly $2-4 \mathrm{~mm}$ in size), sporadically creating miniature helictites [12].
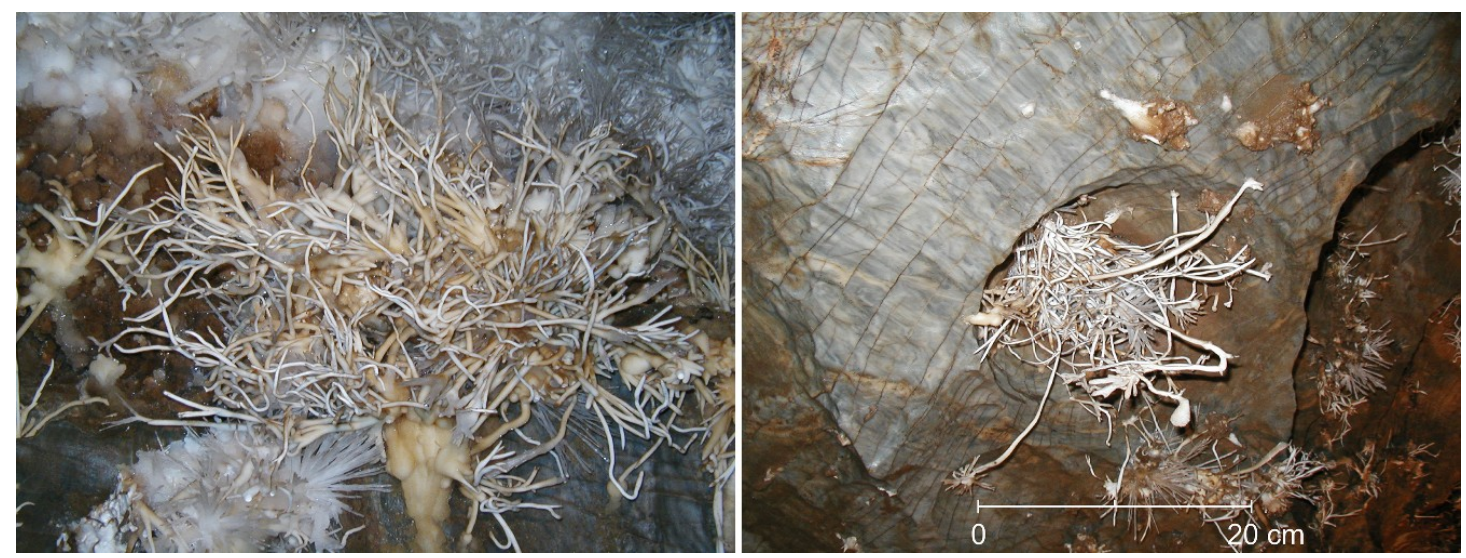

Figure 3. Aragonite formations, Ochtiná Aragonite Cave. 
The Ochtiná Aragonite Cave was discovered accidentally during an excavation of the Kapusta exploratory adit for the evaluation of mineral resources in 1954. The excavation of the tunnel from the surface to the cave enabled its opening to the public in 1972. The entrance of the artificial tunnel into the cave is at an altitude of $642 \mathrm{~m}$.

\section{Methods}

\subsection{Surveying Methods}

\subsubsection{Terrestrial Laser Scanning}

Terrestrial Laser Scanning (TLS) can be considered as a technology suitable for non-contact measurement of spatial coordinates, 3D modeling, and visualization of complex underground structures ([18] and others). During the last years, terrestrial laser scanning has been widely used for the detailed survey of cave spaces and the study of cave morphology ([19-28] and others). The high speed of scanning, accuracy, higher productivity versus common geodetic methods (such as selective measurement of individual points by total stations), significant shortening of fieldwork, and automatic data processing into digital models make this technology almost irreplaceable in rapid speleological mapping. Another important advantage is the use of own source of a laser beam, which ensures hassle-free surveying in poorly illuminated, or even not illuminated underground spaces [29]. Additionally, simpler methods exploiting laser distance measurers were used for capturing cave ceiling morphology [30], but the level of detail recorded does not reach the capabilities of TLS.

A compact all-in-one full panoramic pulse terrestrial laser scanner Leica ScanStation C10 was used for the survey, based on the points of the original survey net (Figure 4). The scanner is equipped with a scanning system based on the Time-of-Flight system (ToF), measuring the given distance based on the transit time of the emitted signal. TLS systems emit intense monochromatic, coherent, and high-directional radiation [31]. Since the laser scanner used in this work is a long-range laser scanner with the mean error in position $6 \mathrm{~mm}$ and mean error of distance measurement $4 \mathrm{~mm}$, we used it as the main instrument for mapping and subsequent 3D modeling of the Ochtiná Aragonite Cave.
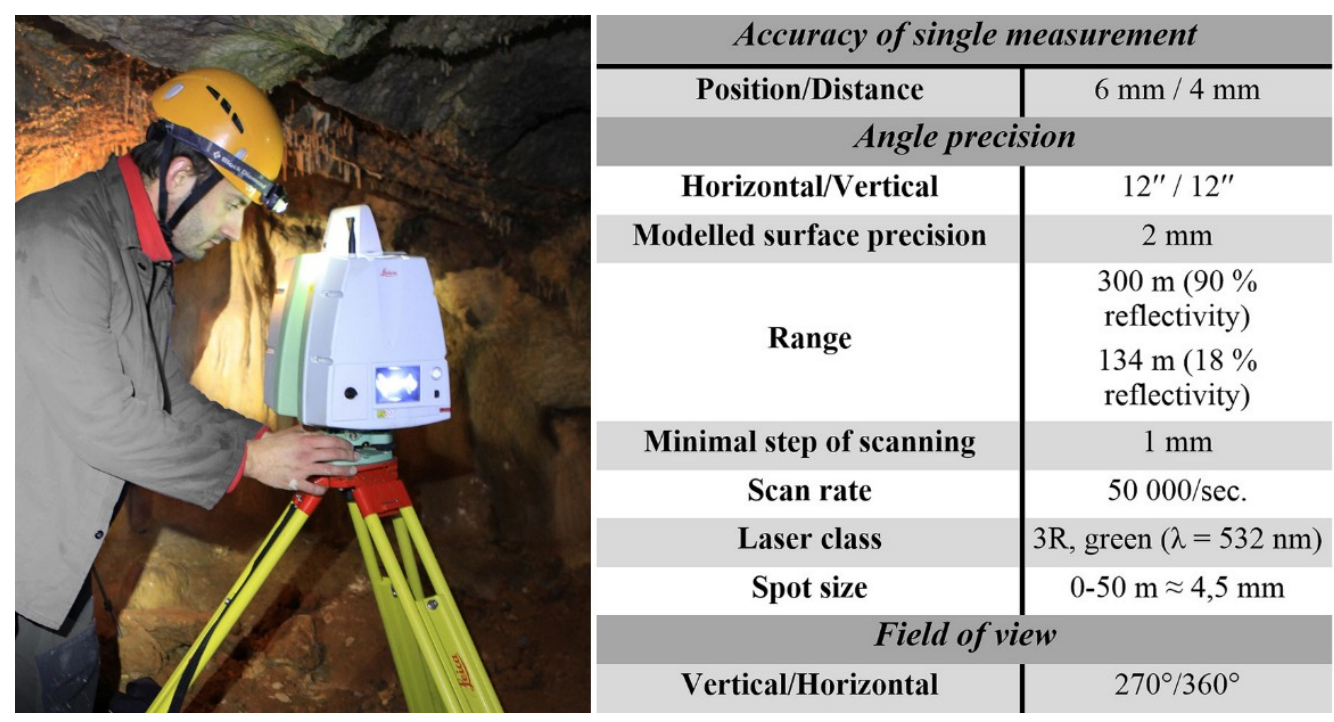

Figure 4. Leica ScanStation C10 during the survey and its technical specification.

During the presented survey, suitable survey stations were chosen after the terrain reconnaissance, while points of the geodetic control monumented in the concrete tourist path were used as initial surveying points. In order to eliminate measurement errors related to the centering of an instrument over fixed survey points, we decided to use the method of dependent centering (the surveying target for scanner orientation is inserted directly into the centering plate instead of the laser scanner and vice 
versa). The highly reflective 6" High Definition Surveying (HDS) targets supplied by the manufacturer were used for registration of scans in the given space. This is the most common registration approach. The coordinates of the centers can be estimated from a number of phase returns covering the surface of the target-target centroiding [32].

Cavities, ponds, tourist path, as well as aragonite decoration, were scanned with high resolution and detail. Overall, more than 121 million points using 54 survey stations placed over survey control points monumented in the concrete tourist path were measured during the laser scanning. The horizontal and vertical resolution on the scanned surface of $20 \times 20 \mathrm{~mm}$ was achieved (Figure 5). The survey was realized in the binding national coordinate system using 10 survey stations located near the cave entrance and in the connecting tunnel. The spatial coordinates of morphological structures were determined in the Slovak national coordinate system and vertical datum by the principle of direct georeferencing [33].

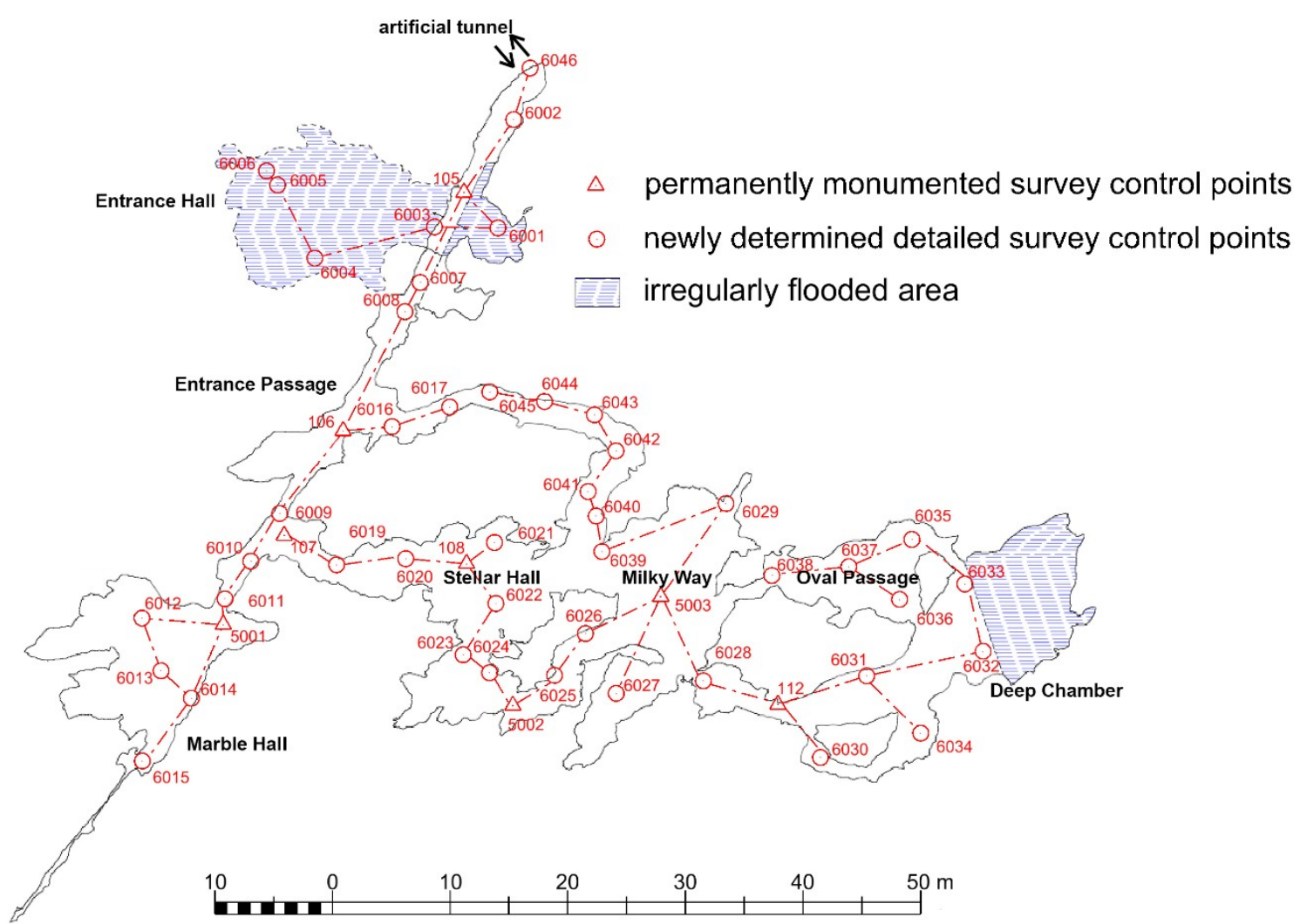

Figure 5. New detailed map of the Ochtiná Aragonite Cave with the overall situation of scanning survey stations.

For the initial processing and editing of the scanned data, a professional 3D point cloud processing software Leica Cyclone version 7.3 (Leica Geosystems AG, Heerbrugg, Switzerland, 2011) was used. For the subsequent editing and modelling, the following software was used: point cloud processing and analysis software Trimble Realworks ${ }^{\circledR}$ Version 10.0.4.441 (Trimble Inc., Sunnyvale, California, United States, 2016) for subsampling and creation of Triangulated Irregular Network (TIN) model; and Computer-aided Designed (CAD) systems-Microstation V8i (Bentley Systems, Inc., PA 19341, United States, 2020) and Leica Cloudworks (Leica Geosystems AG, Heerbrugg, Switzerland, 2011) for the creation of vertical cross-sections. 


\subsubsection{Digital Close-Range Photogrammetry}

For a high-resolution mapping of selected morphologic structures, we decided to use Structure-from-Motion (SfM) method of digital close-range photogrammetry (DCRP).

The SfM photogrammetric method is one of the most advanced methods of processing photogrammetric images. Conventional photogrammetric methods require a set of identical points present on photographic images with their known spatial position. These identical points are then manually identified on individual images, and based on them, the camera position is subsequently determined for each image. In contrast, cameras position and scene geometry in the SfM method are reconstructed simultaneously based on the automatic identification of characteristic matching features-key points, using various algorithms, for example, Scale Invariant Feature Transform (SIFT). These key points allow an initial estimation of cameras position and object coordinates, which are subsequently iteratively refined, for example, by non-linear least-squares minimization. The number of key points identified on images depends primarily on the image resolution and texture of the imaged surface. Density, sharpness, and resolution of a set of images, in combination with a textural variety of the captured scene, will determine the quality of the resulting point cloud. Similarly, the shorter distance between the camera and the imaged surface will increase the spatial resolution of the image and hence increase the density and resolution of the resulting point cloud $[34,35]$.

Appropriate illumination of the imaged surface is a prerequisite for photogrammetric imaging of selected objects. In the case of the Ochtiná Aragonite Cave, it is a show cave accessible for the public, so most of its space is artificially illuminated. Spotlights along the tourist path provide sufficient illumination even for the parts of the cave located farther away from the path. Therefore, no additional illumination was needed. During photogrammetric imaging in such areas, it is necessary to ensure that individual camera stations do not partially or entirely cover the source of illumination and thus avoid undesirable shadows on the imaged surface. However, if illumination in the underground is not sufficient (or not present at all) and, therefore, there is a need for additional artificial illumination of the given spaces, it is necessary to ensure that this illumination is sufficiently strong, constant and stable to prevent variable lighting and the occurrence of undesirable shadows. Otherwise, it could lead to problematic image processing (image orientation, generation of the dense point cloud, lower accuracy, increased noise, etc.) [36].

For photogrammetric survey, all images were captured by digital camera DSLR Pentax K-5 with the lens Pentax SMC DA $15 \mathrm{~mm}$ f/4 ED AL Limited, by using a stable tripod, 12-sec self-timer, ISO 100, aperture $\mathrm{f} / 13$, and RAW format.

For image processing, the Agisoft PhotoScan ${ }^{\circledR}$ Professional Edition (APSC), Version 1.2 software (Agisoft LLC, St. Petersburg, Russia, 2016) for photogrammetric processing of digital images and creation of 3D spatial data was used. Subsequent high-resolution modelling of selected features into a 3D polygonal mesh model was done in the 3D point cloud and mesh processing software CloudCompare version 2.10 (GPL software, 2020).

\section{Results}

\subsection{New Detailed Map and Sections of the Cave}

Given the fact that the scanning at individual survey stations is realized in the local coordinate system of the scanner, we also determined the orientation towards another known survey point in order to make direct georeferencing based on the known coordinates of the 6" HDS targets. After the scanning at all survey stations in the cave, the registration of individual point clouds into the common coordinate system was performed in the Leica Cyclone software. As a result, a database of points that allows the visual inspection of individual shapes of the Ochtiná Aragonite Cave was obtained (Figure 6). 


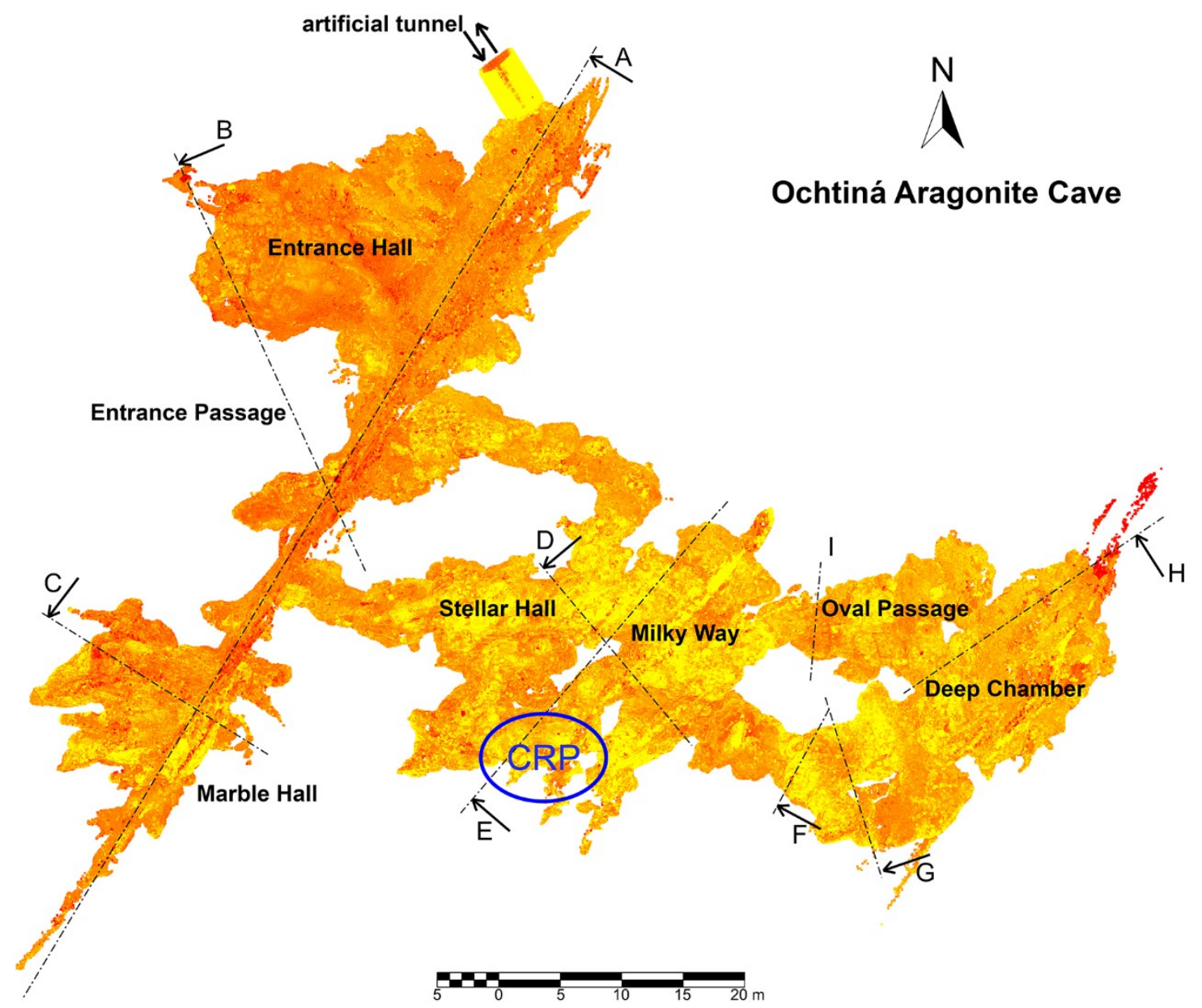

Figure 6. Top view of the final point cloud with a position of cross-sections through the point cloud and site of the survey realized by digital close-range photogrammetry (DCRP).

Resulting from the new survey of the cave by TLS, the area of its ground plan is $1335 \mathrm{~m}^{2}$. In terms of gross morphology and ground plan pattern, the cave is composed of parallel tectonically controlled passages and halls that are interconnected through smaller transverse conduits of phreatic and epiphreatic morphology with numerous ceiling cupolas and smaller spherical cavities, flat ceiling, inward inclined smooth facets, as well as spongework-like hollows. The whole cave represents a labyrinth with a high degree of connectivity.

Vertical cross-sections of individual parts of the cave were created from the point cloud by its subsequent processing in CAD systems-Microstation V8i and Leica Cloudworks (Figure 7). The places of cross-sections ("A"-“I") were selected to view different morphological features significant for the reconstruction of cave origin and development (Figure 6). 

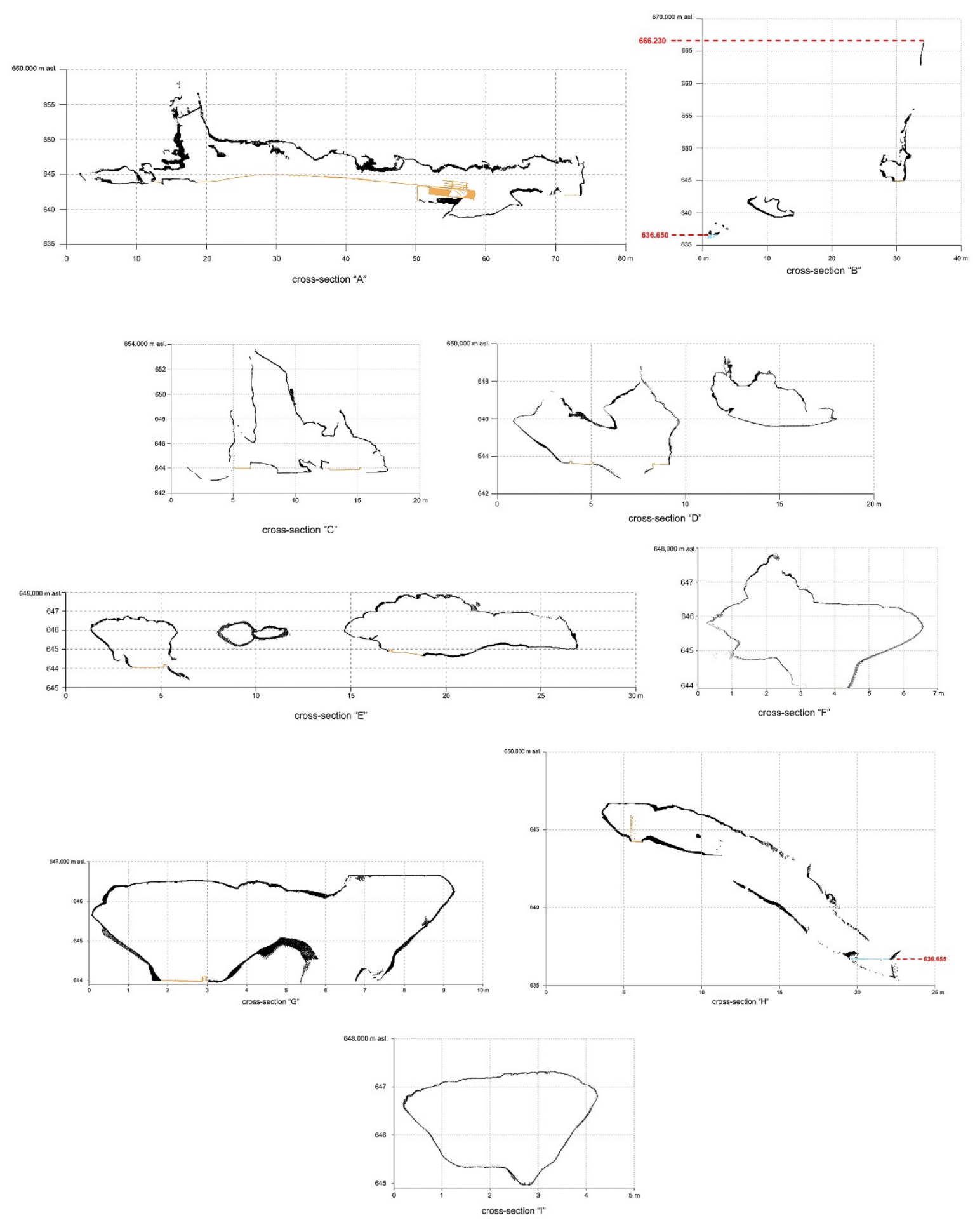

Figure 7. Cross-sections " $\mathrm{A}$ "- "I" of the cave through the final point cloud.

The longitudinal sections A and B show that the Ochtiná Aragonite Cave is a subhorizontal cave, in several places including enlarged ceiling fissures and cupolas, as well as looped conduits below the floor level. Mostly horizontal passages and halls are located in the central part of the cave. They lead east and west into the peripheral tectonically controlled halls. The peripheral halls are featured by lower-lying floors. Measurement data testify the same altitude of the water table of lakes in the Deep Chamber and in the small cavity at the western edge of Entrance Hall (the water table of these lakes 
oscillate synchronously, the whole floor of the Entrance Chamber is flooded at higher water levels). The uppermost place of the cave (A, B; the northern part of the cave) relates to the highest part of the fissure passage leading through the Entrance Hall to the Marble Hall. This passage is controlled by a steep NE-SW fault that predisposed the origin of the western part of the cave (Figure 6 and Figure 12). The lowest places occur at the floor of the Entrance Hall and at the bottom of the Deep Chamber at the lake (B; the western edge of the cave or the NE edge of this chamber). The vertical span of the "dry" part of the cave is $30 \mathrm{~m}$ (Figure 7; cross-section "B"). Since divers have reached a depth of $3 \mathrm{~m}$ below the water table of this lake [37], the total vertical span of the Ochtiná Aragonite Cave is $33 \mathrm{~m}$.

Flat solution ceilings and wall inward-inclined smooth solution facets, typical medium-scale morphological features of the Ochtiná Aragonite Cave [12-14,38], are documented by the cross-sections $\mathrm{G}$ and $\mathrm{H}$. Facets as solution inward-inclined smooth wall surfaces generally maintain a slope of approximately 40-45 degrees, independent of an inclination of bedding planes or lamination [16]. In Ochtiná Aragonite Cave, they were detected in several morphological constellations $[14,38]$. In the transverse passages, facets are mostly associated with a flat ceiling (triangular cross-section-Laughöhle profile after Biese [39]). They are also observed on the lower parts of horizontal or inclined, prevailing oval passages, as well as on the lower parts of halls (the upper edges of these facets are not linear, they are not separated from upper-lying morphologies by wall water table notches). In some places, facets truncate looped phreatic conduits on the walls or floor of passages.

The cross-section F shows another morphostratigraphic relationship-an older ceiling pocket (one of the fragments of primary phreatic morphologies) is truncated by a younger solution flat ceiling that corresponds to the height position of wall water level notches in adjacent parts of the cave. Flat ceilings and associated water table notches deepened into the rock wall of halls and passages are morphological indicators of an epiphreatic developmental phase [12,13,15]. Primary phreatic cavities were enlarged and remodeled along with the stagnant and oscillating groundwater level.

\subsection{D Model of the Cave}

Computer graphics and the development of information technologies are increasingly giving new and better conditions for digital data processing. The issue of creation of 3D surfaces is widespread in the development of new algorithms in computer graphics, as it is also the issue of multiple scientific disciplines [40-44]. For our processing, we used the method of the Triangulated Irregular Network-TIN, where surfaces are represented as a polygonal mesh—vertices, edges, and facets defining the shape of a topographical surface.

For the final surface modeling of the entire cave complex, it was not suitable to use all the scanned points with the original density of points. On the one hand, the point cloud contained a number of unnecessary points that needed to be removed before the processing - such as noise, parts of the technical cave equipment (lighting and electrical installation, tourist path, handrail, etc.), but mainly, the point cloud consisted of several hundred million points, which was extremely demanding for hardware processing. However, any selected parts of the cave can be further processed and analyzed at any time at the original density.

The used Leica Cyclone software works with its custom created database that had to be exported to the exchange *.PTS format. This format provides the export of scanned data in the form of $X$, $\mathrm{Y}$, and $\mathrm{Z}$ coordinates, as well as the intensity of the reflected laser signal from the scanned surface. After the initial processing, data were imported into the Trimble Realworks software and spatially subsampled. To reduce the density of points, we used the method of "spatial sampling" with the defined distance between points $100 \mathrm{~mm}$ to generate a homogeneously composed and reduced point cloud, which was subsequently used to create the TIN model of the cave (Figures 8-10(up)). The spatial localization of the survey into the appropriate coordinate system and vertical datum enables the connection of the final 3D model with the surrounding Digital Terrain Model (DTM) and accurate determination of its positional and vertical span (and other characteristics) (Figure 8). In addition, such a digital model can then be used to derive spatial relationships with the corresponding DTM (or 
another nearby underground structures) for further geo-exploration (for example, geophysical surveys, civil engineering constructions, etc.) (Figure 9).

Although there is always the option to model selected parts of the cave with the full resolution point cloud to obtain a more detailed 3D digital model (Figure 10(down)), the point cloud from TLS will almost never have the same density than the point cloud that can be obtained from digital close-range photogrammetry (see Section 4. Interpretation and Discussion).

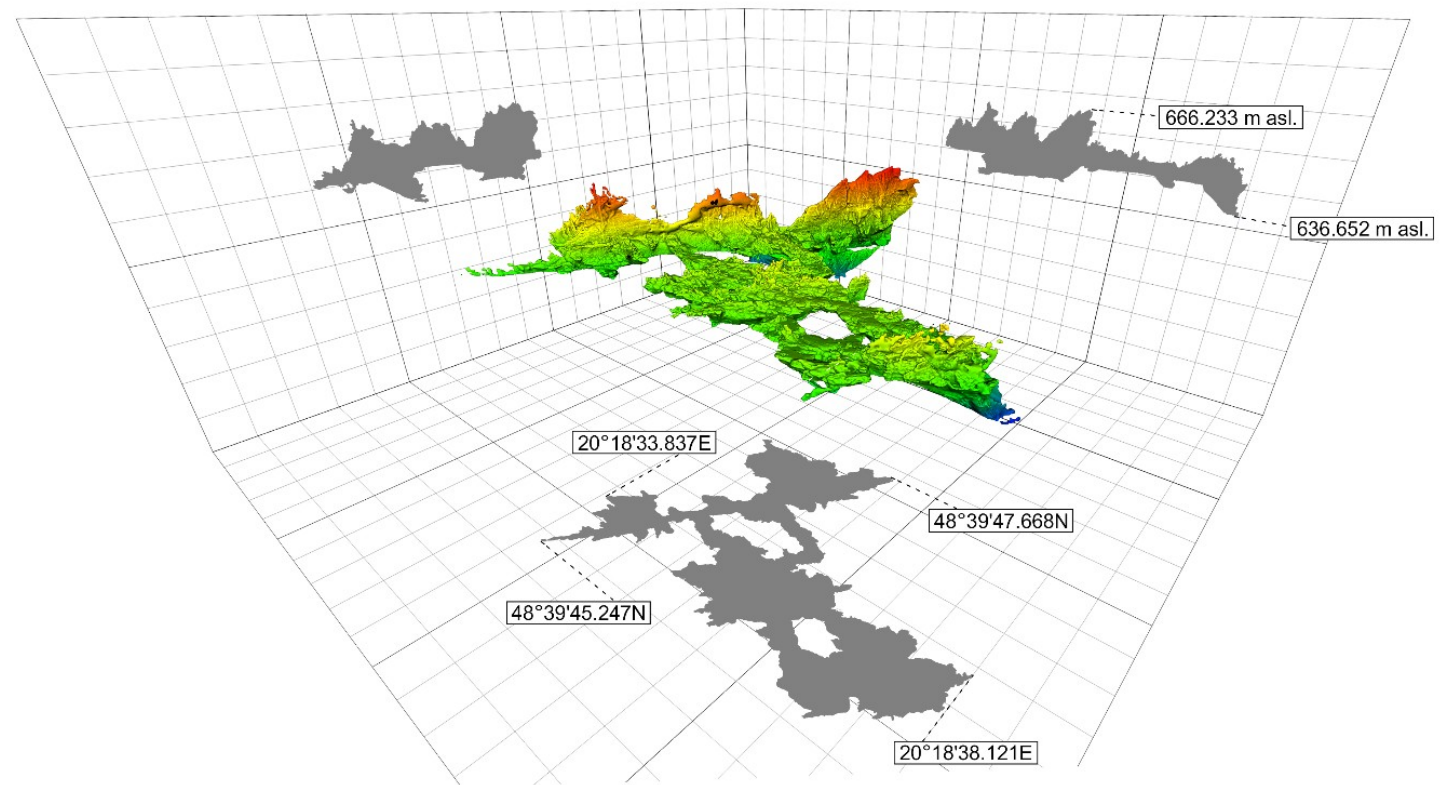

Figure 8. A general overview of the final 3D model by height color ramp; its ground plan and side views.

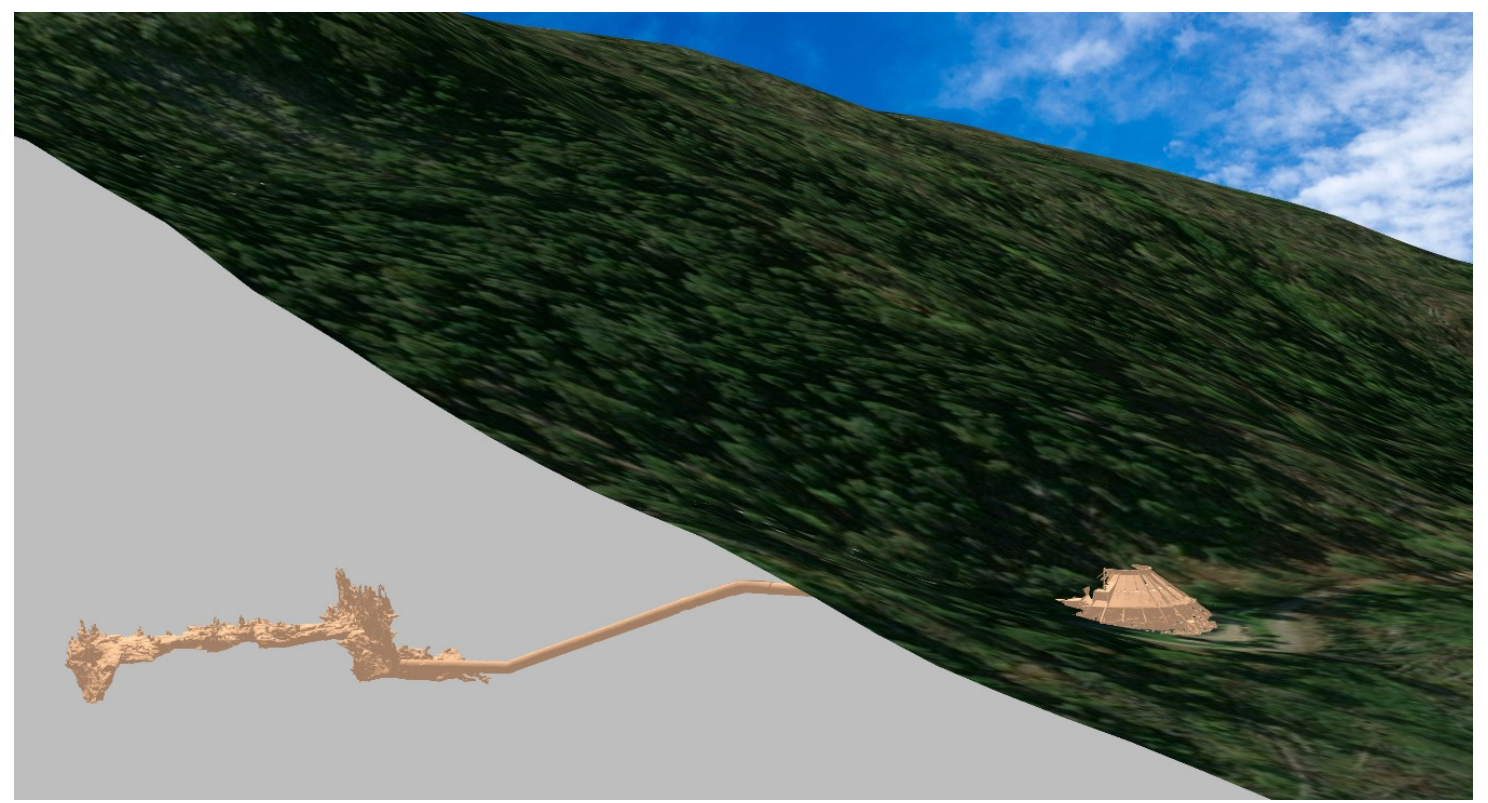

Figure 9. Position of the 3D model of the cave with respect to the surrounding digital terrain model. 

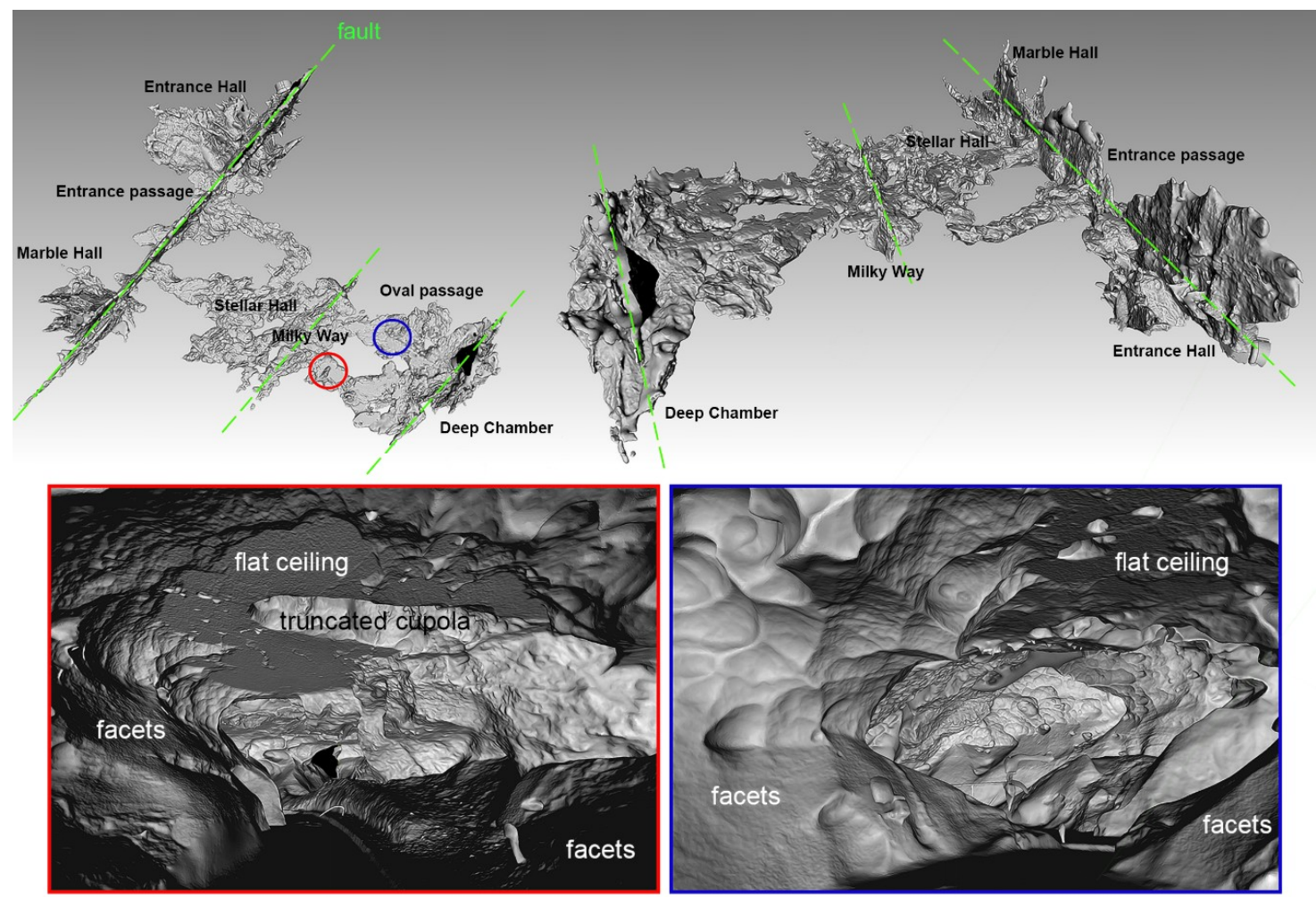

Figure 10. Up - top and isometric perspective view of the final 3D model; down - two inside views of the detailed 3D model created from the full resolution point cloud with characteristics features.

The 3D model illustrates that the Ochtiná Aragonite Cave consists of striking linear passage formed along a steep fault and longer irregular spongework labyrinth of passages and halls (Figure 10). The origin of the central and eastern parts of the cave was conditioned by less striking fractures, more or less parallel with the mentioned significant fault in the western part of the cave (the segment from the Entrance Hall to the Marble Hall). The cave volume is $4424 \mathrm{~m}^{3}$, the circumferential surface of the cave body reaches $7064 \mathrm{~m}^{2}$. The largely irregular and uneven circumferential surface of the cave body relates to numerous medium- and small-scale phreatic and epiphreatic morphologies such as cupolas, ceiling pockets and hollows, niches, or water level notches. Several parts of passages and halls, enlarged and remodeled from original phreatic irregular conduits, are characterized by flat solution ceilings (Laugdecken) and wall inward-sloping smooth solution facets (Facetten/planes of repose; Figure 7; cross-section " $\mathrm{E}$ " and " $\mathrm{G}$ "), in some places forming a flat-roofed triangular cross-section (Laughöhle profile; Figure 7; cross-section "I"). Solution flat ceilings and facets are visible not only on the constructed cross-sections but also on the 3D model of the cave (Figure 10). Observed different solution morphologies, sculptured in the phreatic and epiphreatic zone, refer to a multi-phased origin of the cave by slowly moving and standing water.

\subsection{D Model from the Photogrammetric Survey}

Additionally, some of the specific morphologies of the Ochtiná Aragonite Cave were imaged and photogrammetrically processed. For this paper, one selected part with rock surfaces featured by cusped depressions and sharply contrasting lower-lying inward-sloping smooth solution facets on the cave wall (Figures 6 and 11(left)) was imaged using 62 images at four height levels (Figure 11(right)). A high-resolution of these different morphologies is necessary for a more detail study of their origin, mainly solution facets. Due to the relatively narrow space and therefore limited camera manipulation, all camera stations were chosen to cover the imaged surface with the greatest possible overlap, image density, and convergent image axes. 

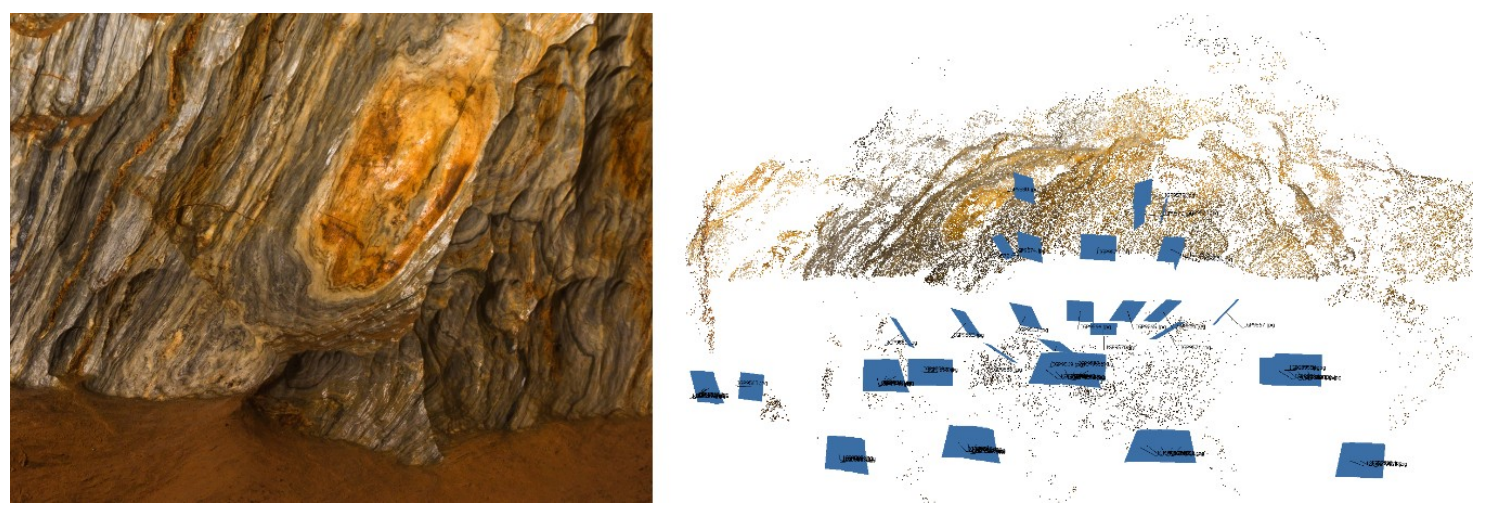

Figure 11. Left—detail of the imaged surface; right—overview of imaging stations.

The final images were subsequently processed in APSC, Version 1.2 software into the form of the textured point cloud (Figure 12). During image processing, the method of field calibration, when calibration parameters are determined during the processing using the project images was used. The resulting point cloud was transformed into the common coordinate system using four ground control points in the form of uniquely identifiable natural points whose coordinates were adopted from laser scanning. Parameters of imaging and image processing are given in Table 1.

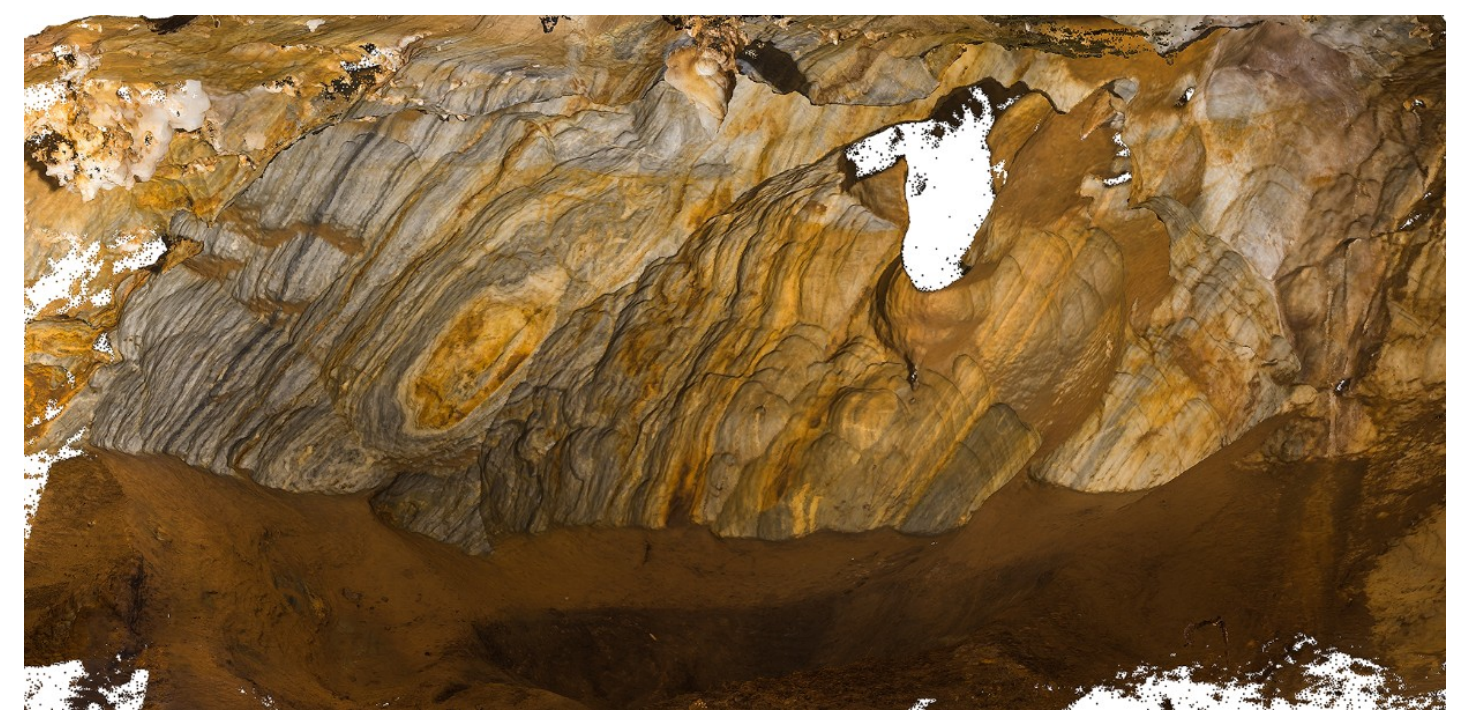

Figure 12. Final photo-textured point cloud from the photogrammetric imaging and processing.

Table 1. Parameters of imaging and image processing in APSC, Version 1.2 software.

\begin{tabular}{cc}
\hline \multicolumn{2}{c}{ Parameters of Imaging and Image Processing } \\
\hline No. of used images & 62 \\
Average imaging distances & $2.5 \mathrm{~m}$ \\
No. of tie points ${ }^{1}$ & 97,000 \\
No. of reconstructed points & $23 \mathrm{mil}$ \\
Ground Sample Distance $^{2}$ & $0.8 \mathrm{~mm}$ \\
Maximal error $^{3}$ & $0.9 \mathrm{pix}$ \\
Reprojection error $^{4}$ & $0.3 \mathrm{pix}$ \\
Accuracy in the reference system $^{5}$ (Total error) & $3.7 \mathrm{~mm}$ \\
\hline
\end{tabular}

\footnotetext{
${ }^{1}$ Tie points represent matches between points (referred to also as "key points") detected on two (or more) different images. ${ }^{2}$ Pixel size in object space units. ${ }^{3}$ Distance between the point on the image where a reconstructed 3D point can be projected, and the original projection of that 3D point detected on the photo and used as a basis for the 3D point reconstruction procedure. ${ }^{4}$ Root mean square reprojection error averaged over all tie points on all images. ${ }^{5}$ Root mean square error of all the ground control points.
} 


\section{Interpretation and Discussion}

\subsection{Surveying Small-Scale Morphologies}

In the case of both technologies, a dense point cloud is the final result of the survey. However, while the laser scan data contains information on the intensity of the reflected signal for each measured point, the photogrammetric data provides textural data in the form of RGB values for each reconstructed point. Although the Leica ScanStation C10 scanner is equipped with an integrated digital camera, this camera provides only low quality and resolution of captured images. Therefore, due to the light conditions in the cave, the integrated camera was not used during the laser scanning.

\section{Comparison of TLS and DCRP}

In order to compare the final data, point clouds obtained by both technologies were compared by a difference model in CloudCompare 2.10 software using the "M3C2 distance" plugin [45], which allows determining robust signed distances directly between two point clouds. Regarding the spatial segmentation, some parts of the Ochtiná Aragonite Cave surveyed by both technologies (morphologically contrast wall surfaces represented by inward-inclined smooth solution facets and the adjacent upper part of the wall with asymmetric cusped depressions). Two smaller parts, showing the areas with the highest deviations, were selected for the comparison. The final difference models, together with the frequency distribution graphs of points and their deviations from the normal distribution (Gaussian curve), are shown in Figure 13.
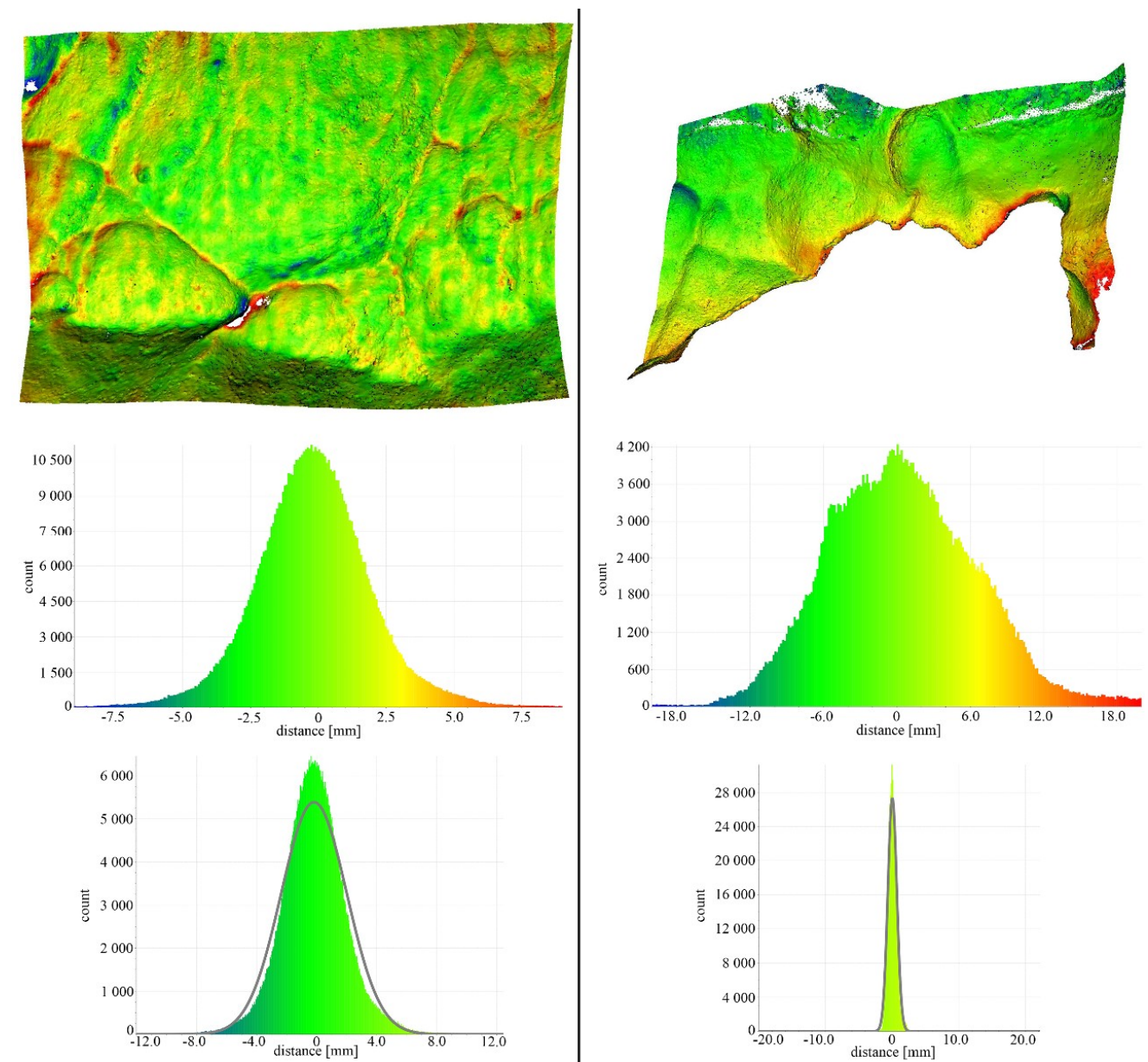

Figure 13. Difference models between two selected parts of the cave wall surface with graphical analysis of their frequency distribution, and their deviations from the normal distribution. 
Both difference models reach the mean value of real deviations of about $0 \mathrm{~mm}(-0.1 \mathrm{~mm}$ and $+0.3 \mathrm{~mm}$ ), with standard deviations of $2 \mathrm{~mm}$ and $6 \mathrm{~mm}$, respectively, representing a minimal, almost zero, mutual change in size between the compared point clouds. All values of deviations range from $-8.3 \mathrm{~mm}$ to $+8.1 \mathrm{~mm}$ (left model), and respectively $-18.8 \mathrm{~mm}$ to $+19.0 \mathrm{~mm}$ (right model). Both distributions of points are sharp, which represents a low variability of deviations. The first (left) difference model has only one sharp peak; therefore, also regarding the size of deviations, there is no systematic error. However, the second (right) difference model does not have such a clear course, and there can be found several partial peaks indicating the influence of systematic errors. In both cases, the largest deviations can be found in areas with the greatest curvature of the model, especially at sharp edges, which is also the result of the higher density of point cloud obtained by photogrammetry with respect to laser scanning.

Another comparison of both models was performed by two vertical cross-sections with a width of $5 \mathrm{~mm}$ through both point clouds (Figure 14). This comparison confirms that the significantly denser point cloud from photogrammetry provides a more detailed and smoother course of the model surface of the selected cave wall than the laser scan data. Additionally, laser scan data points to more significant deviations at sharper edges and transitions, which is also the result of the low density of the scanned data.

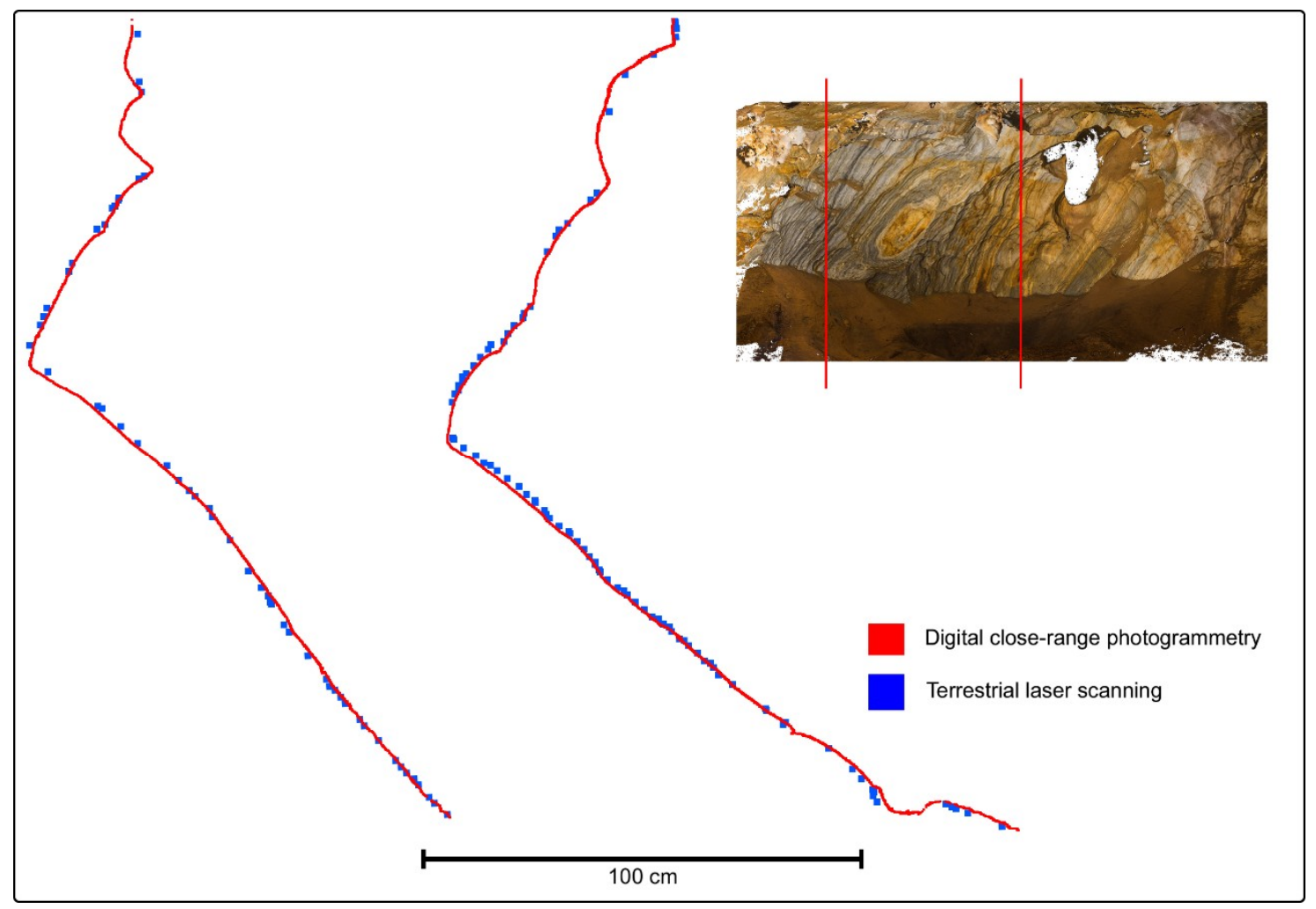

Figure 14. Two vertical cross-sections through both point clouds with their location.

For the modeling of individual morphological cave structures, the mesh models were created from both point clouds and subsequently compared in CloudCompare 2.10 software by Poisson Surface Reconstruction [46] with Octree Depth 12 (Figure 15). According to this Figure, it is obvious that the mesh model generated from the photogrammetric point cloud provides a significantly more detailed representation of morphological structures (although the visualization of two parts of the 3D model in Figure 10 may indicate that TLS point cloud is dense enough). 

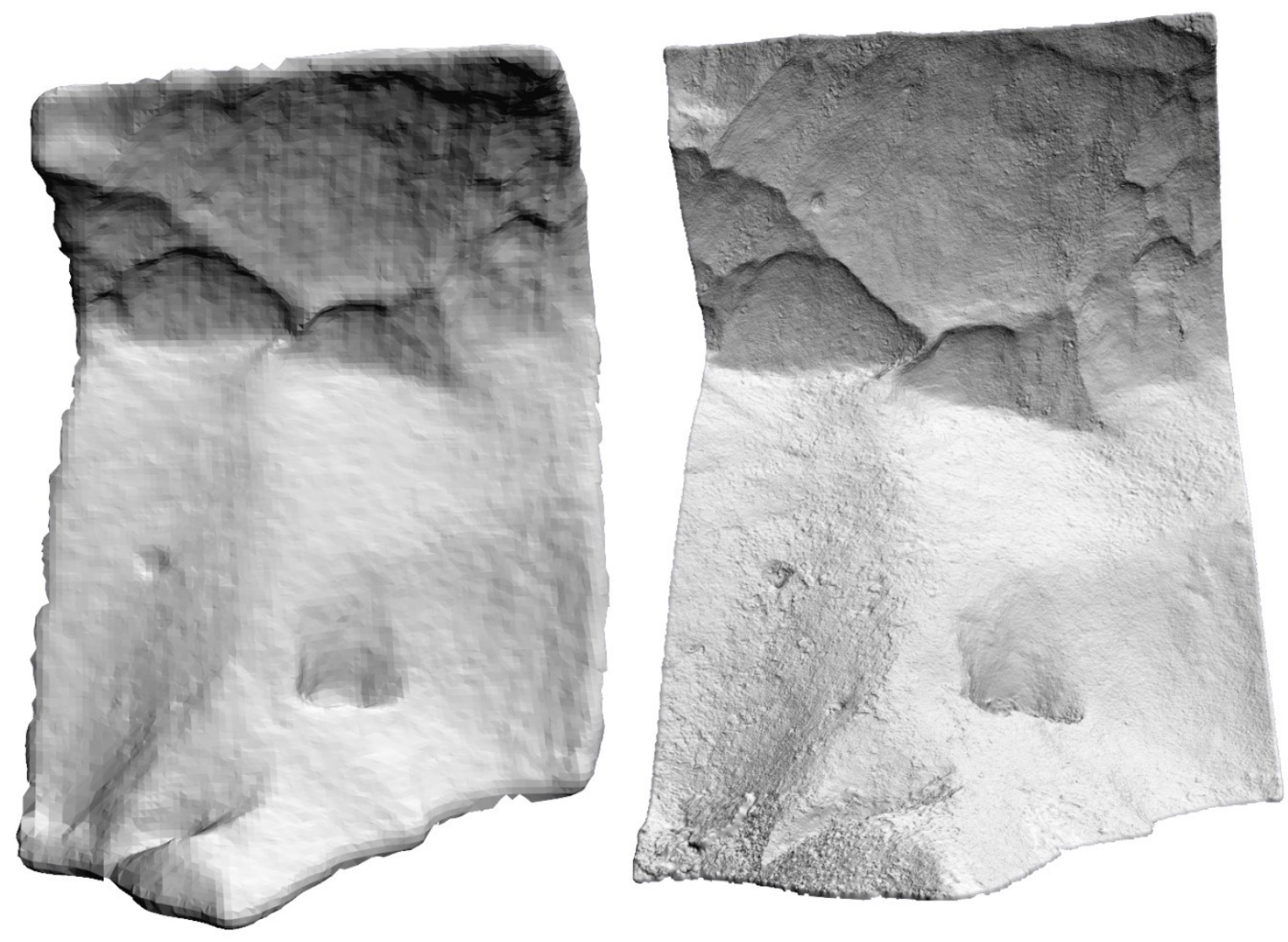

Figure 15. Mesh models created by Poisson Surface Reconstruction with Octree depth 12; left-laser scanning, right-photogrammetry.

Based on these comparisons, it can be stated that both technologies can be suitably used in underground (cave) surveys for the needs of mapping, morphological analyses, etc. Laser scanning provides a rapid measurement of a large number of points, even for large areas, and even without the need for additional illumination of underground spaces. However, its use may be technically, logistically, and financially more demanding, and, in the case of larger areas, the size of the final data output may be excessively large. Digital photogrammetry is financially more affordable and technically less demanding, but its use for large and complex areas would be much more laborious. On the one hand, it also provides textural data on the imaged surface; however, on the other hand, its use is significantly influenced by the illumination in the given areas.

Another important consideration can be done regarding the amount of time and effort it takes to implement these methods. Generally, digital photogrammetry can be less time and effort demanding in terrain survey, since the only terrain process encompasses photogrammetric imaging (including possible illuminating, referencing/scaling). However, the subsequent image processing can be quite demanding, especially in terms of computer's computational power. Furthermore, the surveyor cannot be sure of the quality of the results until the computer image processing is complete. On the other hand, terrestrial laser scanning takes more time and effort in the field (regarding the manipulation with instruments, individual set-ups at survey stations, scanning time, etc.). However, the surveyor can get, and initially quality-check, the point cloud directly after the scanning.

A general comparison of the advantages and disadvantages of both methods is given in Table 2. 
Table 2. A general comparison between Terrestrial Laser Scanning (TLS) and Structure-from-Motion $(\mathrm{SfM})$.

\begin{tabular}{|c|c|c|c|}
\hline & TLS & & SfM \\
\hline$\checkmark$ & $\begin{array}{l}\text { high accuracy guaranteed by the manufacturer } \\
\text { of LS }\end{array}$ & $\checkmark$ & $\begin{array}{l}\text { accuracy comparable to TLS for distances } \\
\text { typical in cave spaces }\end{array}$ \\
\hline$\checkmark$ & quicker terrain survey of complex areas & $\checkmark$ & $\begin{array}{l}\text { high-resolution of small-scale morphological } \\
\text { features }\end{array}$ \\
\hline$\checkmark$ & $\begin{array}{c}\text { artificial targets only for registration of } \\
\text { individual scans }\end{array}$ & $\checkmark$ & more suitable financial demands \\
\hline$\checkmark$ & $\begin{array}{c}\text { direct result of the terrain survey is the final } \\
\text { point cloud }\end{array}$ & $\checkmark$ & easy recording of all parts \\
\hline$\checkmark$ & $\begin{array}{l}\text { no need for special illumination (only if } \\
\text { photo-textured point cloud is not needed) }\end{array}$ & $\checkmark$ & alternate methods of scaling and orientation \\
\hline$x$ & high financial demands & $x$ & need for sufficient artificial illumination \\
\hline$x$ & $\begin{array}{c}\text { instrumentation handling in narrow cave } \\
\text { spaces }\end{array}$ & $x$ & $\begin{array}{c}\text { more time and data demanding survey of } \\
\text { larger areas }\end{array}$ \\
\hline$x$ & more time and effort demanding terrain survey & $x$ & $\begin{array}{l}\text { getting the final data (point cloud) can be } \\
\text { computationally demanding }\end{array}$ \\
\hline
\end{tabular}

\subsection{Implications for the Origin of Some Specific Morphologies}

New surveying of the Ochtiná Aragonite Cave has created a more precise and complete topographic basis for a more detailed study of its morphology, origin, and development.

Within the study of small-scale morphologies, the slightly asymmetrical shape of cusped depressions was documented by their high-resolution visualization. They are observed on the cave walls above inward-sloping smooth solution facets (Figures 13 and 14). These morphologically different and sharply bounded rock shapes on the cave wall originated by limestone dissolution under different conditions.

Since the cusped depressions resemble large scallops (asymmetrical with the downstream and being shallower than the upstream), probably were developed by downward slowly moving water, while smooth facets were not shaped by it. In the sense of [16] (see also [47]), facets as specific solution rock shapes develop during sedimentation of fine-grained insoluble rock particles on the floor and inward-inclined parts of the cave walls that protect the covered bedrock from further dissolution (facets extend upward from initial conduits, only not covered steeper and overhanging parts of the walls and the ceiling are enlarged). According to [15], Facetten (facets) form synchronously with Laugdecken (horizontal/flat ceiling) below a water table. They consider that the dissolution rate along the facets is uniform, and the flat ceiling rises upward at the same time as the facets retreat. However, the facets in Ochtiná Aragonite Cave are not associated only with flat ceilings. They are also known in conduits with an oval ceiling as well as around the halls, almost all parts of the cave.

In addition to that, the floor and flat ceilings in the transverse conduits of the Ochtina Aragonite Cave are not dissected by a central vertical fracture (Figure 7, cross-sections " $\mathrm{G}$ " and " $\mathrm{I}$ "), as assumed by Kempe's model. From these reasons, it is more likely that facets in this cave were probably developed by limestone dissolution under conditions of slowly circulating or stagnating water, possibly assisted by sedimentation of insoluble fine-grained rock particles (in the sense of [16]; see [14,38]). The Ochtiná Aragonite Cave is a very important site for a study of the origin of solution facets on the limestone walls.

\section{Conclusions}

Surveying the Ochtiná Aragonite Cave with terrestrial laser scanning provided the most actual and precise map of this very remarkable cave. This map, in several sectors refined by surveying with digital photogrammetry, is an important tool for a more detailed study of cave morphology including its structural and tectonic control as well as medium- and small-scale solution forms (ceiling cupolas 
and smaller spherical cavities, flat ceilings, facets, cusped depressions, and some other morphologies originated in slowly moving or standing water). Morphostratigraphical cross-cutting relationships of some rock shapes, documented by several cross-sections of cave passages, reflect the main speleogenetic phases of the cave, especially the transition between phreatic and epiphreatic sculpturing resulting from the water table drop and its stagnation. Moreover, the terrestrial laser scanning made it possible to determine the basic surface and volumetric values of the cave. On the other hand, digital close-range photogrammetry allows obtaining detailed photo-textured 3D models of selected morphological structures in a relatively short time and with a high density of final data.

Since both technologies have specific requirements, advantages, and disadvantages (accuracy, financial demands, demands of work especially in narrow cave spaces, and illumination of the surface); therefore, the combination of these methods has been shown as the most suitable for detailed mapping of complex cave spaces and capturing all of their specific features. The TLS makes it possible to obtain accurate spatial data on the overall shape and extension of underground spaces in a short time, while digital close-range photogrammetry (namely the SfM method) provides tools for very-high-resolution mapping of small-scale morphologies with the ability to use photo-texture from digital images, so a comprehensive data on the overall morphology in the most accurate and detailed way can be created.

Since the Ochtiná Aragonite Cave has opened to the public, the results of its new surveying are useable also for a solution of some other tasks related to human impacts on the cave environment; for example, microclimatic changes due to the movements of visitors in cave parts with different volumes and their negative influences on the fragile aragonite formations (following the studies of Klaučo [48]; and others).

Author Contributions: Conceptualization, P.B. (Pavel Bella) and J.G.; methodology, K.P., K.B., and P.B. (Pavel Bella); software, L'.K.; validation, P.B. (Pavel Bella) and P.B. (Peter Blistan); formal analysis, K.P. and K.B.; investigation, K.P., K.B., and P.B. (Pavel Bella); resources, P.B. (Pavel Bella); data curation, J.G. and L'.K.; writing-original draft preparation, K.B. and P.B. (Pavel Bella); writing-review and editing, K.P., K.B., P.B. (Pavel Bella), and P.B. (Peter Blistan); visualization, K.B.; supervision, P.B. (Pavel Bella), J.G., and P.B. (Peter Blistan); project administration, K.P. and P.B. (Pavel Bella); funding acquisition, K.P. and P.B. (Peter Blistan). All authors have read and agreed to the published version of the manuscript.

Funding: This work was supported by the grants No. 1/0030/12, 1/0844/18 and 1/0146/19 funded by the Scientific Grant Agency of The Ministry of Education, Science, Research and Sport of the Slovak Republic (VEGA); and the grant No. 004TUKE-4/2019 funded by the Cultural and Educational Agency of The Ministry of Education, Science, Research and Sport of the Slovak Republic (KEGA).

Acknowledgments: We would like to thank the Slovak Caves Administration for the permission with 3D laser scanning, digital photogrammetry, and geomorphological research in Ochtiná Aragonite Cave. Many thanks to the reviewers and the editor for their useful comments and suggestions.

Conflicts of Interest: The authors declare no conflict of interest. The funders had no role in the design of the study; in the collection, analyses, or interpretation of data; in the writing of the manuscript, or in the decision to publish the results.

\section{References}

1. Ševčík, R.; Kantor, J. Aragonitová jaskyňa na Hrádku pri Jelšave. Geologické Práce, Zprávy 1956, 7, 161-171.

2. Droppa, A. Ochtinská aragonitová jaskyňa. Geografický Čas. 1957, 9, 169-184.

3. Sýkora, J. Základná mapa Ochtinskej aragonitovej jaskyne, číselná a ostatná dokumentácia: Manuscript 1983.

4. Sýkora, J. Meranie A Mapovanie Ochtinskej Aragonitovej Jaskyne. In Proceedings of the Výskum, Využivanie A Ochrana Jaskýň, Zborník Referátov Z 1. Vedeckej Konferencie, SSJ, Liptovský Mikuláš, Slovakia, 8-10 October 1997; pp. 147-150.

5. Sýkora, J. Ochtinská aragonitová jaskyňa, profily a rezy: Manuscript 1985.

6. Gažík, P. Geografický informačný systém technických prvkov v Ochtinskej aragonitovej jaskyni. Slovenský Kras 2004, 42, 137-139.

7. Grecula, P. Gemerikum-Segment Riftogfénneho Bazénu Paleotetýdy II; Mineralia Slovaca: Bratislava, Slovakia, 1982.

8. Gaál, L'. Geológia Ochtinskej aragonitovej jaskyne. Slovenský Kras 2004, 42, 37-56. 
9. Homza, Š.; Rajman, L.; Roda, Š. Vznik a vývoj krasového fenoménu Ochtinskej aragonitovej jaskyne. Slovenský Kras 1970, 8, 21-68.

10. Gaál, L'.; Ženiš, P. Kras Revúckej vrchoviny. Slovenský Kras 1986, 24, $27-60$.

11. Rajman, L.; Roda, ك̌., Jr.; Roda sen, Š.; ك̌čuka, J. Unterchungen über die Genese der Aragonithöhle von Ochtiná (Slowakei). Die Höhle 1993, 44, 1-8.

12. Bosák, P.; Bella, P.; Cílek, V.; Ford, D.C.; Hercman, H.; Kadlec, J.; Osborne, A.; Pruner, P. Ochtiná Aragonite Cave (Western Carpathians, Slovakia): Morphology, Mineralogy of the Fill and Genesis. Geol. Carpath. 2002, 53, 399-410.

13. Bella, P.; Bosák, P.; Gaál, L'.; Pruner, P.; Haviarová, D. Ochtinská aragonitová jaskyňa-špecifický typ hypogénnej jaskyne? Aragonit 2017, 20, 65-66.

14. Bella, P. Geomorfologické pomery Ochtinskej aragonitovej jaskyne. Slovenský Kras 2004, 42, 57-88.

15. Kempe, S.; Brandt, A.; Seeger, M.; Vladi, F. "Facetten" and "Laugdecken", the typical morphological elements of caves developed in standing water. Annales Des Spéléologie 1975, 30, 705-708.

16. Lange, A. Planes of repose in caves. Cave Notes 1963, 5, 41-48.

17. Ford, D.C.; Williams, P.W. Karst Hydrogeology and Geomorphology; Wiley: Chichester, UK, 2007.

18. Cui, H.; Hu, Q.; Mao, Q.; Song, M. Spiral trajectory planning approach for underground cavity measurements based on laser scanning. Measurement 2017, 110, 166-175. [CrossRef]

19. Canavese, E.P.; Forti, P.; Naseddu, A.; Ottelli, L.; Tedeschi, R. Laser scanning technology for the hypogean survey: The case of Santa Barbara karst system (Sardinia, Italy). Acta Carsologica 2011, 40. [CrossRef]

20. Jaillet, S.; Sadier, B.; Hajri, S.; Ployon, E.; Delannoy, J.-J. Une analyse 3D de l'endokarst : Applications lasergrammétriques sur l'aven d'Orgnac (Ardèche, France). Geomorphologie 2011, 17, 379-394. [CrossRef]

21. Cosso, T.; Ferrando, I.; Orlando, A. Surveying and mapping a cave using $3 \mathrm{~d}$ laser scanner: The open challenge with free and open source software. Int. Arch. Photogramm. Remote Sens. Spat. Inf. Sci. 2014, 45, 181-186. [CrossRef]

22. Gallay, M.; Kaňuk, J.; Hochmuth, Z.; Meneely, J.; Hofierka, J.; Sedlák, V. Large-scale and high-resolution 3-D cave mapping by terrestrial laser scanning: A case study of the Domica Cave, Slovakia. Int. J. Speleol. 2015, 44, 277-291. [CrossRef]

23. Gallay, M.; Hochmuth, Z.; Kaňuk, J.; Hofierka, J. Geomorphometric analysis of cave ceiling channels mapped with 3-D terrestrial laser scanning. Hydrol. Earth Syst. Sci. 2016, 20, 1827-1849. [CrossRef]

24. Silvestre, I.; Rodrigues, J.; Figueiredo, M.; Veiga-Pires, C. High-resolution digital 3D models of Algar do Penico Chamber: Limitations, challenges, and potential. Int. J. Speleol. 2015, 44, 25-35. [CrossRef]

25. Idrees, M.O.; Pradhan, B. A decade of modern cave surveying with terrestrial laser scanning: A review of sensors, method and application development. Int. J. Speleol. 2016, 45, 71-88. [CrossRef]

26. Idrees, M.O.; Pradhan, B. Characterization of Macro-and Micro-Geomorphology of Cave Channel from High-Resolution 3D Laser Scanning Survey: Case Study of Gomantong Cave in Sabah, Malaysia. In Cave Investigation; Karabulut, S., Cinku, M.C., Eds.; InTech: London, UK, 2017; ISBN 978-953-51-3331-5.

27. Fabbri, S.; Sauro, F.; Santagata, T.; Rossi, G.; De Waele, J. High-resolution 3-D mapping using terrestrial laser scanning as a tool for geomorphological and speleogenetical studies in caves: An example from the Lessini mountains (North Italy). Geomorphology 2017, 280, 16-29. [CrossRef]

28. De Waele, J.; Fabbri, S.; Santagata, T.; Chiarini, V.; Columbu, A.; Pisani, L. Geomorphological and speleogenetical observations using terrestrial laser scanning and 3D photogrammetry in a gypsum cave (Emilia Romagna, N. Italy). Geomorphology 2018, 319, 47-61. [CrossRef]

29. Štroner, M.; Pospíšil, J.; Koska, B.; Křemen, T.; Urban, R.; Smítka, V.; Třasák, P. 3D Skenovací Systémy; České Vysoké Učení Technické v Praze: Praha, Czechia, 2013.

30. Lundberg, J.; McFarlane, D.A. Post-speleogenetic biogenic modification of Gomantong Caves, Sabah, Borneo. Geomorphology 2012, 157, 153-168. [CrossRef]

31. Štroner, M.; Pospíšil, J. Terestrické Skenovací Systémy; České Vysoké Učení Technické v Praze: Praha, Czechia, 2008.

32. Reshetyuk, Y. Terrestrial Laser Scanning; VDM Verlag Dr. Müller: Saarbrücken, Germany, 2009.

33. Gordon, S.J. Structural Deformation Measurement Using Terrestrial Laser Scanners. Ph.D. Thesis, Curtin University of Technology, Department of Spatial Science, Bentley, Australia, 2005. 
34. Peña-Villasenín, S.; Gil-Docampo, M.; Ortiz-Sanz, J. 3-D Modeling of Historic Façades Using SFM Photogrammetry Metric Documentation of Different Building Types of a Historic Center. Int. J. Archit. Herit. 2017, 11, 871-890. [CrossRef]

35. Westoby, M.J.; Brasington, J.; Glasser, N.F.; Hambrey, M.J.; Reynolds, J.M. 'Structure-from-Motion' photogrammetry: A low-cost, effective tool for geoscience applications. Geomorphology 2012, 179, 300-314. [CrossRef]

36. Pukanská, K.; Bartoš, K.; Bella, P.; Rákay ml., Š.; Sabová, J. Comparison of non-contact surveying technologies for modelling underground morphological structures. Acta Montan. Slovaca 2017, 22, 246-256.

37. Hochmut, Z. Problémy Speleologického Prieskumu Podzemných Tokov Na Slovensku 1; Slovenská speleologická spoločnost': Prešov-Košice, Slovakia, 2000; ISBN 966963-4-3.

38. Bella, P. Korózne šikmé facety v jaskyniach a ich morfogenetické znaky-príklady z vybraných jaskýň na Slovensku. Aragonit 2013, 18, 78-84.

39. Biese, W.; Über Höhlenbildung, I. Über Höhlenbildung, I. Teil. Entstehung Der Gipshölen Am Südlichen Harzrad und Am Kyffhäuser; Abhandlung Der Preußischen Geologischen Landsanstalt; NF: Berlin, Germany, 1931.

40. Quaas, S.; Rudolph, H.; Luthardt, R.G. Direct mechanical data acquisition of dental impressions for the manufacturing of CAD/CAM restorations. J. Dent. 2007, 35, 903-908. [CrossRef]

41. Tafti, A.P.; Kirkpatrick, A.B.; Alavi, Z.; Owen, H.A.; Yu, Z. Recent advances in 3D SEM surface reconstruction. Micron 2015, 78, 54-66. [CrossRef]

42. Li, X.; Chen, J.; Zhu, H. A new method for automated discontinuity trace mapping on rock mass 3D surface model. Comput. Geosci. 2016, 89, 118-131. [CrossRef]

43. Xiao, D.; Fang, F.; Pain, C.C.; Navon, I.M. Towards non-intrusive reduced order 3D free surface flow modelling. Ocean Eng. 2017, 140, 155-168. [CrossRef]

44. Chen, X.; Possel, J.K.; Wacongne, C.; van Ham, A.F.; Klink, P.C.; Roelfsema, P.R. 3D printing and modelling of customized implants and surgical guides for non-human primates. J. Neurosci. Methods 2017, 286, 38-55. [CrossRef] [PubMed]

45. Lague, D.; Brodu, N.; Leroux, J. Accurate 3D comparison of complex topography with terrestrial laser scanner: Application to the Rangitikei canyon (N-Z). ISPRS J. Photogramm. Remote Sens. 2013, 82, 10-26. [CrossRef]

46. Bolitho, M.; Kazhdan, M.; Burns, R.; Hoppe, H. Multilevel Streaming for Out-of-Core Surface Reconstruction. In Proceedings of the 5th Eurographics Symposium on Geometry Processing, Barcelona, Spain, 4-6 July 2007; pp. 69-78.

47. Goodman, L.R. Planes of repose in Höllern, Germany. Cave Notes 1964, 6, 17-19.

48. Klaučo, S.; Filová, J.; Zelinka, J. Vplyv návštevnosti Na Speleoklímu Ochtinskej Aragonitovej Jaskyne. In Proceedings of the Výskum, Využívanie A Ochrana jaskýň, Zborník Referátov Z 1 Vedeckej Konferencie; SSJ: Liptovský Mikuláš, Slovakia, 1998; pp. 75-86.

(C) 2020 by the authors. Licensee MDPI, Basel, Switzerland. This article is an open access article distributed under the terms and conditions of the Creative Commons Attribution (CC BY) license (http://creativecommons.org/licenses/by/4.0/). 